\title{
Studies of Uni-Univalent lon Exchange Reactions Using Strongly Acidic Cation Exchange Resin Amberlite IR-120
}

\author{
Pravin Singare ${ }^{1}$, Ram Lokhande ${ }^{2}$, Neelima Samant ${ }^{3}$ \\ ${ }^{1}$ Department of Chemistry, Bhavan's College, Andheri, Mumbai, India \\ ${ }^{2}$ Department of Chemistry, University of Mumbai, Vidyanagari, Santacruz, Mumbai, India \\ ${ }^{3}$ Department of Chemistry, Sathaye College, Vile Parle, Mumbai, India
}

Received 15 June 2009; revised 22 July 2009; accepted 25 July 2009.

\begin{abstract}
The selectivity behaviour of ion exchange resin Amberlite IR-120 for inorganic cations like sodium and potassium was predicted on the basis of thermodynamic data. The equilibrium constant $K$ values calculated for uni-univalent ion exchange reaction systems were observed to increase with rise in temperature, indicating endothermic ion exchange reactions. From the $K$ values calculated at different temperatures the enthalpy values were calculated. The low enthalpy and higher $K$ values for $\mathrm{K}^{+}$ion exchange reaction indicates more affinity of the resin for potassium ions as compared to that for sodium ions also in the solution. The technique used in the present experimental work will be useful in understanding the selectivity behaviour of different ion exchange resins for ions in the solution. Although the ionic selectivity data for the ion exchange resins is readily available in the literature, it is expected that the information obtained from the actual experimental trials will be more helpful. The technique used in the present experimental work when applied to different ion exchange resins will help in there characterization.
\end{abstract}

Keywords: Ion Exchange Equilibrium; Equilibrium Constant; Enthalpy; Endothermic Reaction;

Amberlite IR-120

\section{INTRODUCTION}

There are number of liquid processes waste streams at chemical processing, nuclear power plants, nuclear fuel reprocessing plants and nuclear research centers that requires treatment for removal of various contaminants. One of the most common treatment methods for such aqueous streams is the use of ion exchange, which is a well developed technique that has been employed for many years in chemical as well as nuclear industries. While designing an ion exchange liquid waste processing system it is desirable to have an adequate knowledge about the distribution coefficient values and the selectivity behaviour of these ion exchange resin towards different ions present in liquid waste. Generally the selected ion exchange materials must be compatible with the chemical nature of the waste such as type and concentration of ionic species present as well as the operating parameters notably temperature. Considerable work was done by previous researchers to study the properties of the ion exchange resins, to generate thermodynamic data related to various uni-univalent and heterovalent ion exchange systems [1-6]. A number of researchers carried out equilibrium studies, extending over a wide range of composition of solution and resin phase [7-27]. Attempts were also made to study the temperature effect on anion exchange systems [10,22-29] for computing the thermodynamic equilibrium constants. However, very little work was carried out to study the equilibrium of cation exchange systems [7-21]. Therefore in the present investigation attempts were made to study the thermodynamics of uni-univalent cation exchange equilibrium, the results of which will be of considerable use in explaining the selectivity of ion exchanger for various univalent ions in solution.

\section{EXPERIMENTAL}

The ion exchange resin Amberlite IR-120 as supplied by the manufacturer (Rohm and Hass Co.,USA) was a strongly acidic cation exchange resins in $\mathrm{H}^{+}$form containing $8 \%$ S-DVB of 16-50 mesh size, having moisture content of $\sim 45 \%$. The maximum operating temperature is $120^{\circ} \mathrm{C}$, operating in the $\mathrm{pH}$ range of $0-14$. The exchange capacity of the resin is $1.9 \mathrm{meq} / \mathrm{mL}$ on wetted bed volume basis. For present investigation, the resin grains of 30-40 mesh size were used. The conditioning of the resins was done by usual methods [23-26]. 
The ion exchange resins in $\mathrm{H}^{+}$form weighing $0.500 \mathrm{~g}$ were equilibrated with $\mathrm{Na}^{+}$ion solution of different concentrations at a constant temperature of $30.0^{\circ} \mathrm{C}$ for 3 h. From the results of kinetics study reported earlier [30-41]; it was observed that this duration was adequate to attain the ion exchange equilibrium. After $3 \mathrm{~h}$ the different $\mathrm{Na}^{+}$ion solutions in equilibrium with ion exchange resins were analyzed for their $\mathrm{H}^{+}$ion concentration by potentiometric titration with standard $0.1 \mathrm{~N}$ $\mathrm{NaOH}$ solution. From the results $\boldsymbol{K}$ value for the reaction

$$
\mathrm{R}-\mathrm{H}^{+} \mathrm{Na}^{+}{ }_{\text {(aq.) }} \rightleftharpoons \mathrm{R}-\mathrm{Na}+\mathrm{H}^{+} \text {(aq.) }
$$

was determined at $30.0{ }^{\circ} \mathrm{C}$. Similar values of $\boldsymbol{K}$ for the above $\mathrm{H}^{+} / \mathrm{Na}^{+}$system was determined for different temperatures in the range of $30.0{ }^{\circ} \mathrm{C}$ to $40.0{ }^{\circ} \mathrm{C}$.

The study was also carried out as explained above for $\mathrm{H}^{+} / \mathrm{K}^{+}$system in the same temperature range, to study the $\boldsymbol{K}$ values for the reaction

$$
\mathrm{R}-\mathrm{H}+\mathrm{K}^{+}{ }_{\text {(aq.) }} \rightleftharpoons \mathrm{R}-\mathrm{K}+\mathrm{H}^{+}{ }_{\text {(aq.) }}
$$

The sodium and potassium ion solutions used in the entire experimental work, where prepared by dissolving potassium and sodium chloride salts (Analytical grade) in distilled deionised water. In the present study, a semimicro burette having an accuracy of $0.05 \mathrm{~mL}$ was used in the titrations and the titration readings were accurate to $\pm 0.05 \mathrm{~mL}$. Considering the magnitude of the titer values, the average equilibrium constants reported in the experiment are accurate to $\pm 3 \%$.

\section{RESULTS AND DISCUSSION}

The equilibrium constants for the uni-univalent ion exchange reactions ( 1 and 2 ) would be given by the expression

$$
\boldsymbol{K}=\frac{\mathrm{C}_{\mathrm{RX}} \cdot \mathrm{C}_{\mathrm{H}}^{+}}{\left(\mathrm{A}-\mathrm{C}_{\mathrm{RX}}\right) \cdot \mathrm{C}_{\mathrm{X}}^{+}}
$$

here $\mathrm{A}$ is the ion exchange capacity of the resin, $\mathrm{x}^{+}$ represents $\mathrm{Na}^{+}$or $\mathrm{K}^{+}$ions.

For different concentrations of $\mathrm{x}^{+}$ions in solution at a given temperature, $\boldsymbol{K}$ values was calculated from which average value of $\boldsymbol{K}$ for that set of experiment was calculated. Similar values of $\boldsymbol{K}$ were calculated for both $\mathrm{H}^{+} / \mathrm{Na}^{+}$and $\mathrm{H}^{+} / \mathrm{K}^{+}$systems for different temperatures (Table 1).

Earlier researchers have expressed the concentration of ions in the solution in terms of molality and concentration of ions in resin in terms of mole fraction [21]. In view of above, the experimental results obtained in the present study have been substituted in the following equation by Bonner et al. $[14,18]$ and the equilibrium constant $\boldsymbol{K}$ ' was calculated (Table 2).

$$
\boldsymbol{K}^{\prime}=\frac{\left[\mathrm{N}_{\mathrm{x}}^{+}\right]\left[\mathrm{m}^{+}\right]}{\left[\mathrm{NH}^{+}\right]\left[\mathrm{m}_{\mathrm{x}}^{+}\right]}
$$

here $\mathrm{N}_{\mathrm{X}}^{+}=$mole fraction of $\mathrm{K}^{+}$or $\mathrm{Na}^{+}$ions exchanged on the resin

$\mathrm{m}_{\mathrm{H}}^{+}=$molality of $\mathrm{H}^{+}$ions exchanged in the solution

$\mathrm{N}_{\mathrm{H}}^{+}=$mole fraction of $\mathrm{H}^{+}$ions remained on the resin

$\mathrm{m}_{\mathrm{x}}^{+}=$molality of $\mathrm{K}^{+}$or $\mathrm{Na}^{+}$ions remained in the solution at equilibrium.

Since in the present study the solution was dilute, the molality and molarity of the ions in the solution were almost the same, with negligible error. Therefore the molality of the ions can be easily replaced by molarity. The equilibrium constant $\boldsymbol{K}^{\prime}$ ' was calculated by Eq. 4 and the average value of $\boldsymbol{K}^{\prime}$ is reported (Table 2). Such $\boldsymbol{K}^{\prime}$ values were calculated for different temperatures and the values were in good agreement with $\boldsymbol{K}$ values calculated by Eq.3 (Table 1 and Table 2).This justifies that the choice of units for the concentration in the present study is insignificant. The enthalpy value for the ion exchange reactions 1 and 2 were calculated by plotting the graph of $\log \boldsymbol{K}$ against 1/T (Figure 1). Bonner and Pruett [14] studied the temperature effect on uni-univalent exchanges involving some bivalent ions. In all bivalent exchanges the equilibrium constant decreases with rise in temperature resulting in exothermic reactions. However in the present investigation, the equilibrium constant values increases with rise in temperature (Table 1 and Table 2), indicating the endothermic ion exchange reactions [23-26]. The low enthalpy and higher $\boldsymbol{K}$ values for $\mathrm{H}^{+} / \mathrm{K}^{+}$exchange as compared to that for $\mathrm{H}^{+} / \mathrm{Na}^{+}$exchange (Table 1 and Table 2 ), indicate that the resins in $\mathrm{H}^{+}$form are having more affinity for larger ionic size $\mathrm{K}^{+}$ ions in solution as compared to that for $\mathrm{Na}^{+}$ions also in the solution.

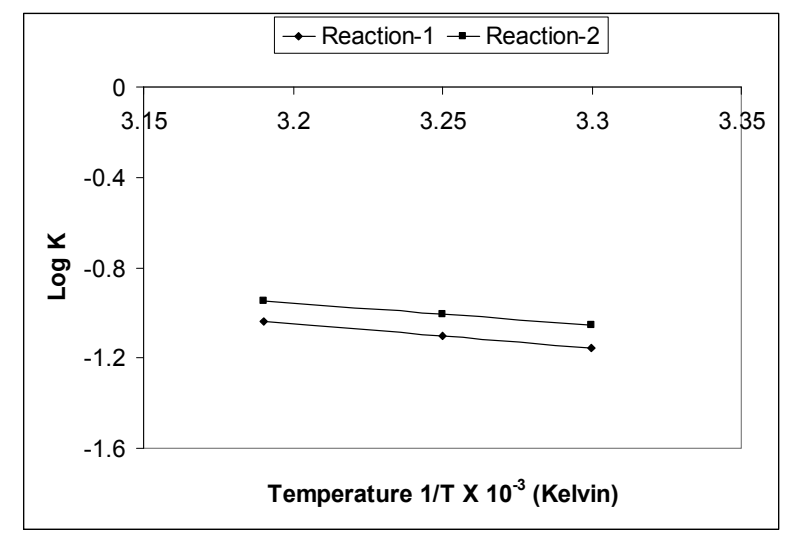

Figure 1. Variation of Equilibrium Constant with Temperature for the Ion Exchange Reactions (1) And (2) Using Ion Exchange Resin Amberlite IR-120. Amount of the ion exchange resin in $\mathrm{H}^{+}$form $=0.500 \mathrm{~g}$, Temperature Range $=$ $30.0^{\circ} \mathrm{C}-40.0^{\circ} \mathrm{C}$. 
Table 1. Equilibrium constant for the uni-univalent ion exchange reactions using ion exchange resin Amberlite IR-120. Amount of the ion exchange resin in $\mathrm{H}^{+}$form $=0.500 \mathrm{~g}$, Ion exchange capacit $\mathrm{y}=3.3 \mathrm{meq} . \mathrm{g}$, Volume of external ionic solution $=80.0 \mathrm{~mL}$

\begin{tabular}{|c|c|c|c|c|c|c|c|c|c|c|}
\hline \multicolumn{6}{|c|}{ Reaction 1} & \multicolumn{5}{|c|}{ Reaction 2} \\
\hline \multicolumn{11}{|c|}{ Temperature $=30.0{ }^{\circ} \mathrm{C}$} \\
\hline $\begin{array}{l}\text { Initial } \\
\text { conc. of } \\
\mathrm{Na}^{+} \text {ion } \\
\text { solution } \\
\text { (M) }\end{array}$ & $\begin{array}{c}\text { Final } \\
\text { conc.of } \\
\mathrm{Na}^{+} \text {ions } \\
(\mathrm{M}) \\
\mathrm{C}_{\mathrm{Na}}^{+}\end{array}$ & $\begin{array}{l}\text { Conc. of } \\
\mathrm{H}^{+} \text {ions } \\
\text { Exchanged } \\
\text { in solution } \\
(\mathrm{M}) \mathrm{C}_{\mathrm{H}}^{+}\end{array}$ & & $\begin{array}{l}\text { Amount of } \\
\mathrm{Na}^{+} \text {ions } \\
\text { Exchanged } \\
\text { on the resin } \\
\text { meq./ } 0.5 \mathrm{~g} \\
\mathrm{C}_{\mathrm{RNa}}\end{array}$ & $\begin{array}{c}\text { Equilibrium } \\
\text { constant } \\
\mathrm{K}\end{array}$ & $\begin{array}{l}\text { Initial } \\
\text { Conc. } \\
\text { of } \mathrm{K}^{+} \text {ion } \\
\text { solution } \\
\quad(\mathrm{M})\end{array}$ & $\begin{array}{c}\text { Final conc. } \\
\text { of } \mathrm{K}^{+} \text {ions } \\
(\mathrm{M}) \\
\mathrm{C}_{\mathrm{K}}^{+}\end{array}$ & $\begin{array}{l}\text { Conc. of } \\
\mathrm{H}^{+} \text {ions } \\
\text { exchanged } \\
\text { in solution } \\
(\mathrm{M}) \\
\mathrm{C}_{\mathrm{H}}^{+}\end{array}$ & $\begin{array}{c}\text { Amount of } \\
\mathrm{K}^{+} \text {ions } \\
\text { Exchanged } \\
\text { on the resin } \\
\text { meq. } / 0.5 \mathrm{~g} \\
\mathrm{C}_{\mathrm{RK}}\end{array}$ & $\begin{array}{c}\text { Equilibrium } \\
\text { constant } \\
\mathrm{K}\end{array}$ \\
\hline 0.01 & 0.0052 & 0.0048 & & 0.24 & 0.072 & 0.01 & 0.0048 & 0.0052 & 0.26 & 0.099 \\
\hline 0.02 & 0.0126 & 0.0074 & & 0.37 & 0.074 & 0.02 & 0.0120 & 0.0080 & 0.40 & 0.099 \\
\hline 0.025 & 0.0166 & 0.0084 & & 0.42 & 0.074 & 0.025 & 0.0160 & 0.0090 & 0.45 & 0.096 \\
\hline 0.03 & 0.0208 & 0.0108 & & 0.46 & 0.072 & 0.03 & 0.0200 & 0.0100 & 0.50 & 0.096 \\
\hline 0.04 & 0.0292 & 0.0112 & & 0.54 & 0.072 & 0.04 & 0.0282 & 0.0118 & 0.59 & 0.098 \\
\hline \multicolumn{6}{|c|}{$\begin{array}{l}\text { Average equilibrium constant }(K)=0.073 \\
\text { Standard deviation }(\mathrm{s})= \pm 0.001\end{array}$} & \multicolumn{5}{|c|}{$\begin{array}{l}\text { Average equilibrium constant }(K)=0.098 \\
\text { Standard deviation }(\mathrm{s})= \pm 0.001\end{array}$} \\
\hline \multicolumn{2}{|c|}{$\begin{array}{l}\text { Temperature } \\
{ }^{\circ} \mathrm{C}\end{array}$} & 30.0 & 35.0 & 40.0 & $\begin{array}{l}\text { Enthalpy } \\
(\mathrm{kJ} / \mathrm{mol})\end{array}$ & 30.0 & \multicolumn{2}{|c|}{35.0} & 40.0 & $\begin{array}{l}\text { Enthalpy } \\
(\mathrm{kJ} / \mathrm{mol})\end{array}$ \\
\hline \multicolumn{2}{|c|}{$\begin{array}{l}\text { Equilibrium } \\
\text { Constant }(K)\end{array}$} & 0.073 & 0.079 & 0.094 & 19.9 & 0.098 & \multicolumn{2}{|c|}{0.107} & 0.120 & 15.0 \\
\hline
\end{tabular}

Table 2. Equilibrium constant for the uni-univalent ion exchange reactions using ion exchange resin Amberlite IR-120 calculated by Bonner et.al. Equation.

Amount of the ion exchange resin in $\mathrm{H}^{+}$form $=0.500 \mathrm{~g}$, Ion exchange capacity $=3.3 \mathrm{meq} . / \mathrm{g}$, Volume of external ionic solution $=80.0 \mathrm{~mL}$

\begin{tabular}{|c|c|c|c|c|c|c|c|c|c|c|}
\hline \multicolumn{6}{|c|}{ Reaction 1} & \multicolumn{5}{|c|}{ Reaction 2} \\
\hline \multicolumn{11}{|c|}{ Temperature $=30.0{ }^{0} \mathrm{C}$} \\
\hline $\begin{array}{l}\text { Initial } \\
\text { conc. of } \\
\mathrm{Na}^{+} \text {ion } \\
\text { solution } \\
\text { (M) }\end{array}$ & $\begin{array}{c}\text { Final } \\
\text { conc. of } \\
\mathrm{H}^{+} \text {ions } \\
(\mathrm{M}) \\
\mathrm{C}_{\mathrm{Na}}^{+}\end{array}$ & \multicolumn{2}{|c|}{$\begin{array}{c}\text { Mole fraction } \\
\text { of } \mathrm{Na}^{+} \text {ions } \\
\text { exchanged } \\
\text { on the resin } \\
\mathrm{N}_{\mathrm{Na}}^{+}\end{array}$} & $\begin{array}{c}\text { Mole } \\
\text { fraction } \\
\text { of } \mathrm{H}^{+} \text {ions } \\
\text { remained on } \\
\text { the resin } \\
\mathrm{N}_{\mathrm{H}}^{+}\end{array}$ & $\begin{array}{c}\text { Equilibrium } \\
\text { constant } \\
\mathrm{K}^{\prime}\end{array}$ & $\begin{array}{l}\text { Initial } \\
\text { Conc. } \\
\text { of } \mathrm{K}^{+} \text {ion } \\
\text { solution } \\
\text { (M) }\end{array}$ & $\begin{array}{c}\text { Final conc. } \\
\text { of } \mathrm{K}^{+} \\
\text {Ions } \\
(\mathrm{M}) \\
\mathrm{C}_{\mathrm{K}}^{+}\end{array}$ & $\begin{array}{c}\text { Mole } \\
\text { fraction of } \\
\mathrm{K}^{+} \text {ions } \\
\text { Exchanged } \\
\text { on the resin } \\
\mathrm{N}_{\mathrm{K}}^{+}\end{array}$ & $\begin{array}{c}\text { Mole } \\
\text { fraction of } \\
\mathrm{H}^{+} \text {ions } \\
\text { Remained } \\
\text { on theresin } \\
\mathrm{N}_{\mathrm{H}}^{+}\end{array}$ & $\begin{array}{c}\text { Equilibrium } \\
\text { constant } \\
\mathrm{K}^{\prime}\end{array}$ \\
\hline 0.01 & 0.0052 & \multicolumn{2}{|c|}{0.073} & 0.927 & 0.072 & 0.01 & 0.0048 & 0.079 & 0.921 & 0.093 \\
\hline 0.02 & 0.0126 & \multicolumn{2}{|c|}{0.112} & 0.888 & 0.074 & 0.02 & 0.0120 & 0.012 & 0.879 & 0.092 \\
\hline 0.025 & 0.0166 & \multicolumn{2}{|c|}{0.127} & 0.873 & 0.074 & 0.025 & 0.0160 & 0.136 & 0.864 & 0.089 \\
\hline 0.03 & 0.0208 & \multicolumn{2}{|c|}{0.164} & 0.836 & 0.081 & 0.03 & 0.0200 & 0.152 & 0.849 & 0.089 \\
\hline 0.04 & 0.0292 & \multicolumn{2}{|c|}{0.170} & 0.830 & 0.075 & 0.04 & 0.0282 & 0.179 & 0.821 & 0.091 \\
\hline \multicolumn{6}{|c|}{$\begin{array}{l}\text { Average equilibrium constant }(K)=0.075 \\
\text { Standard deviation }(\mathrm{s})= \pm 0.004\end{array}$} & \multicolumn{5}{|c|}{$\begin{array}{l}\text { Average equilibrium constant }(K)=0.091 \\
\text { Standard deviation }(\mathrm{s})= \pm 0.002\end{array}$} \\
\hline \multicolumn{2}{|c|}{$\begin{array}{l}\text { Temperature } \\
{ }^{\circ} \mathrm{C}\end{array}$} & 30.0 & 35.0 & 40.0 & $\begin{array}{l}\text { Enthalpy } \\
(\mathrm{kJ} / \mathrm{mol})\end{array}$ & 30.0 & 35.0 & 40.0 & \multicolumn{2}{|c|}{$\begin{array}{l}\text { Enthalpy } \\
(\mathrm{kJ} / \mathrm{mol})\end{array}$} \\
\hline \multicolumn{2}{|c|}{$\begin{array}{l}\text { Equilibrium } \\
\text { Constant }\left(K^{\prime}\right)\end{array}$} & 0.075 & 0.079 & 0.094 & 19.9 & 0.091 & 0.099 & 0.111 & \multicolumn{2}{|c|}{15.0} \\
\hline
\end{tabular}




\section{CONCLUSION}

Efforts to develop new ion exchangers for specific applications are continuing. In spite of their advanced stage of development, various aspects of ion exchange technologies have been continuously studied to improve the efficiency and economy in various technical applications. The selection of an appropriate ion exchange material is possible on the basis of information provided by the manufacturer. However, it is expected that the data obtained from the actual experimental trials will prove to be more helpful. The thermodynamic data obtained in the present experimental work will be useful to understand the selectivity behaviour of ion exchange resins for various ions in solution thereby helping in characterization of resins.

\section{REFERENCES}

[1] Bhargava, A. and Janardanan, C. (1997) Ion exchange properties of bismuth antimonite. Indian J. Chem., 36А(7), 624-625.

[2] Muraviev, D., Gonzalo, A. and Valiente, M. (1995) Ion exchange on resins with temperature-responsive selectivity. 1. Ion-Exchange Equilibrium of $\mathrm{Cu}^{2+}$ and $\mathrm{Zn}^{2+}$ on Iminodiacetic and Aminomethylphosphonic Resins. Anal. Chem., 67(17), 3028-3035.

[3] Boyd, G.E., Vaslow, F. and Lindenbaum, S. (1967) Thermodynamic quantities in the exchange of zinc with sodium ions in variously cross-linked polystyrene sulfonate cation exchangers at 25. degree. J. Phys. Chem., 71(7), 2214-2219.

[4] Duncan, J.F. (1955) Enthalpies and entropies of ion-exchange reactions. Australian Journal of Chemistry, 8(1), 1-20.

[5] Boyd, G.E., Vaslow, F. and Lindenbaum, S. (1964) Calorimetric determinations of the heats of ion-exchange reactions. I. Heats of exchange of the alkali metal cations in variously cross-linked polystyrene sulfonates. J. Phys. Chem., 68(3), 590-597.

[6] Schwarz, A. and Boyd, G.E. (1965) Thermodynamics of the exchange of tetramethylammonium with sodium ions in cross-linked polystyrene sulfonates at $25^{\circ}$. J. Phys. Chem., 69(12), 4268-4275.

[7] Myers, G.E. and Boyd, G.E. (1956) A thermodynamic calculation of cation exchange selectivities. J. Phys. Chem., 60(5), 521-529.

[8] Bonner, O.D. (1955) Ion-exchange equilibria involving rubidium, cesium and thallous ions. J. Phys. Chem., 59(8), 719-721.

[9] Bonner, O.D. (1954) A selectivity scale for some monovalent cations on Dowex 50. J. Phys. Chem., 58(4), 318-320.

[10] Lindenbaum, S., Jumper, C.F. and Boyd, G.E. (1959) Selectivity coefficient measurements with variable capacity cation and anion exchangers. J. Phys. Chem., 63(11), 1924-1929.

[11] Kraus, K.A. and Raridon, R.J. (1959) Temperature dependence of some cation exchange equilibria in the range
0 to $200^{\circ} \mathrm{C}$. J. Phys. Chem., 63(11), 1901-1907.

[12] Bonner, O.D. and Payne, W.H. (1954) Equilibrium studies of some monovalent ions on Dowex 50. J. Phys. Chem., 58(2), 183-185.

[13] Argersinger, W.J. and Davidson, A.W. (1952) Experimental factors and activity coefficients in ion exchange equilibria. J. Phys. Chem., 56(1), 92-96.

[14] Bonner, O.D. and Pruett, R.R. (1959) The effect of temperature on ion exchange equilibria. III. Exchanges Involving Some Divalent Ions, J. Phys. Chem., 63(9), 1420-1423.

[15] Bonner, O.D. and Livingston, F.L. (1956) Cation-exchange equilibria involving some divalent ions. J. Phys. Chem., 60(5), 530-532.

[16] Bonner, O.D. and Smith, L.L. (1957) A selectivity scale for some divalent cations on Dowex 50. J. Phys. Chem. 61(3), 326-329.

[17] Bonner, O.D., Jumper, C.F. and Rogers, O.C. (1958) Some cation-exchange equilibria on Dowex 50 at $25^{\circ} . J$. Phys. Chem., 62(2), 250-252.

[18] Bonner O.D. and Smith L.L. (1957) The effect of temperature on ion-exchange equilibria. I. The Sodium-Hydrogen and Cupric-Hydrogen Exchanges, $J$. Phys. Chem., 61(12), 1614-1617.

[19] Kielland J. (1935) Thermodynamics of base-exchange equilibria of some different kinds of clays. J. Soc. Chem. Ind., (London) 54, 232-234.

[20] Vanselow A.P. (1932) The utilization of the base-exchange reaction for the determination of activity coefficients in mixed electrolytes. J. Am. Chem. Soc., 54(4), 1307-1311.

[21] Gaines, G.L. (Jr.) and Thomas, H.C. (1953) Adsorption studies on clay minerals. II. A Formulation of the Thermodynamics of Exchange Adsorption. J. Chem. Phys., 21(4), 714-718.

[22] Kraus, K.A., Raridon, R.J. and Holcomb, D.L. (1960) Anion exchange studies: A column method for measurement of ion exchange equilibria at high temperature. Temperature coefficient of the $\mathrm{Br}^{-}-\mathrm{Cl}^{-}$exchange reaction, Chromatogr. J., 3(1), 178-179.

[23] Lokhande, R.S., Singare, P.U. and Patil, A.B. (2007) A study of ion exchange equilibrium for some uni-univalent and uni-divalent reaction systems using strongly basic anion exchange resin Indion-830 (Type 1). Russ. J. Phys. Chem. A, 81(12), 2059-2063.

[24] Singare, P.U., Lokhande, R.S. and Prabhavalkar, T.S. (2008) Thermodynamics of ion exchange equilibrium for some uni-univalent and divalent reaction systems using strongly basic anion exchange resin Indion FF-IP. Bull. Chem. Soc. Ethiop., 22(3), 415-421.

[25] Lokhande R.S. and Singare P.U. (2007) Study on ion exchange equilibrium for some uni-univalent reaction systems using strongly basic anion exchange resin Amberlite IRA-400. J. Ind. Council Chem., 24(2), 73-77.

[26] Lokhande R.S., Singare P.U. and Kolte A.R. (2008) Ion exchange equilibrium for some uni-univalent and uni-divalent reaction systems using strongly basic anion exchange resin Duolite A-102 D. Bull. Chem. Soc. Ethiop., 22(1), 107-114.

[27] Heumann, K.G. and Baier, K. (1982) Chloride distribution coefficient on strongly basic anion-exchange resin: Dependence on co-ion in alkali fluoride solutions. 
Chromatographia, 15(11), 701-703.

[28] Lokhande, R.S., Singare, P.U. and Karthikeyan, P. (2008) Study on ion exchange equilibrium using strongly basic anion exchange resin Duolite A-162. J. Ind. Council Chem., 25(2), 117-121.

[29] Singare, P.U., Lokhande, R.S., Kolte, A.R., Dole, M.H., Karthikeyan, P. and Parab, S.A. (2008) Studies on ion exchange equilibrium using some anion exchange resins, Int. J. Chem. Sci., 6(4), 2172-2181.

[30] Lokhande R.S., Singare P.U. and Patil A.B. (2007) Application of radioactive tracer technique on Industrialgrade ion exchange resins Indion-830 (Type-1) and Indion-N-IP (Type-2). Radiochim. Acta, 95(1), 111-114.

[31] Lokhande, R.S. and Singare, P.U. (2007) Comparative study on ion-isotopic exchange reaction kinetics by application of tracer technique, Radiochim. Acta, 95(3), 173-176.

[32] Lokhande, R.S., Singare, P.U. and Kolte, A.R. (2007) Study on kinetics and mechanism of ion-isotopic exchange reaction using strongly basic anion exchange resins Duolite A-101 D and Duolite A-102 D. Radiochim. Acta, 95(10), 595-600.

[33] Lokhande, R.S., Singare, P.U. and Dole, M.H. (2006) Comparative study on bromide and iodide ion-Isotopic exchange reactions using strongly basic anion exchange resin Duolite A-113, J. Nucl. Radiochem. Sci., 7(2), 29-32.

[34] Lokhande, R.S. and Singare, P.U. (2008) Comparative study on iodide and bromide ion-isotopic exchange reactions by application of radioactive tracer technique, J.Porous Mater, 15(3), 253-258.

[35] Lokhande, R.S., Singare, P.U. and Karthikeyan, P. (2007) The kinetics and mechanism of bromide ion isotope ex- change reaction in strongly basic anion-exchange resin Duolite A-162 determined by the radioactive tracer technique, Russ. J. Phys. Chem. A, 81(11), 1768-1773.

[36] Lokhande, R.S., Singare, P.U. and Dole, M.H. (2007) Application of radiotracer technique to study the ion isotope exchange reactions using a strongly basic anion-exchange resin Duolite A-113. Radiochemistry, 49(5), 519-522.

[37] Singare, P.U., Lokhande, R.S. and Patil, A.B. (2008) Application of radioactive tracer technique for characterization of some strongly basic anion exchange resins, $R a$ diochim. Acta, 96(2), 99-104.

[38] Lokhande, R.S., Singare, P.U. and Tiwari, S.R.D. (2008) Study of bromide ion-isotopic exchange reaction kinetics using a weakly basic macro porous resin Indion-860. Radiochemistry, 50(6), 633-637.

[39] Lokhande, R.S., Singare, P.U. and Prabhavalkar, T.S. (2008) The application of the radioactive tracer technique to study the kinetics of bromide isotope exchange reaction with the participation of strongly basic anion exchange resin Indion FF-IP. Russ. J. Phys. Chem. A, 82(9), 1589-1595.

[40] Lokhande, R.S., Singare, P.U. and Parab, S.A. (2008) Application of radioactive tracer technique to study the kinetics of iodide ion-isotopic exchange reaction using strongly basic anion exchange resin Duolite A-116, $R a$ diochemistry, 50(6), 642-644.

[41] Lokhande, R.S., Singare, P.U. and Patil, V.V. (2008) Application of radioactive tracer technique to study the kinetics and mechanism of reversible ion-isotopic exchange reaction using strongly basic anion exchange resin Indion-850, Radiochemistry, 50(6), 638-641. 